\title{
Influence of Zn Injection on Corrosion of 304SS Under PWR Primary Side Conditions
}

\author{
Haibo Wei ${ }^{1,2}$, Jingwei Lin ${ }^{3}$, Zhikun $\operatorname{Liu}^{2}$, Lina $W u^{2}$ and Lisheng Chi ${ }^{2 *}$ \\ ${ }^{1}$ College of Chemical and Materials Science, Fujian Normal University, Fuzhou, China, ${ }^{2}$ Fujian Key Laboratory of Fuel and Materials \\ in Clean Nuclear Energy System, Fujian Institute of Research on the Structure of Matter, CAS, Fuzhou, China, ${ }^{3}$ Ocean School, \\ Fuzhou University, Fuzhou, China
}

The structural materials in nuclear power plants experience corrosion under high temperature water chemistry environments, which could result in serious safety issues. Zinc injection to the primary side chemistry has been demonstrated to reduce corrosion rate of the structural materials and radiation dose rate by modifying the oxide film formed on the structural materials. The purpose of this work is to investigate the effect of $\mathrm{Zn}$ addition at different concentrations on 304SS under PWR primary side conditions by SEM, GIXRD, Raman spectrum, XPS, electrochemical method and thermodynamic calculation.

OPEN ACCESS

Edited by:

Hao Zhang,

Jiangxi Science and Technology Normal University, China

Reviewed by:

Ali Dad Chandio,

NED University of Engineering and

Technology, Pakistan

Qiao Yanxin,

Jiangsu University of Science and

Technology, China

*Correspondence:

Lisheng Chi

Ichi@fijrsm.ac.cn

Specialty section:

This article was submitted to Polymeric and Composite Materials,

a section of the journal

Frontiers in Materials

Received: 11 December 2021 Accepted: 14 February 2022

Published: 28 February 2022

Citation:

Wei H, Lin J, Liu Z, Wu L and Chi L (2022) Influence of Zn Injection on Corrosion of 304SS Under PWR

Primary Side Conditions.

Front. Mater. 9:833291.

doi: 10.3389/fmats.2022.833291
When $\mathrm{Zn}$ concentration is increased, the number and size of Fe-based spinel oxide particles in the outer layer decreases while Cr-based spinel oxide in the inner layer remains unchanged. The corrosion current density of 304SS and defect density of the oxide film decrease with increasing $\mathrm{Zn}$ concentration. These results conclude that corrosion resistance of 304SS is enhanced in the presence of $\mathrm{Zn}$. In addition, the thermodynamic analyses on the spinel oxides of surface were performed and the results are in good agreement with the experimental observations presented in this work.

Keywords: Zn injection, 304 stainless steel, XPS, high-temperature oxidation, solubilities

\section{INTRODUCTION}

The structural materials, such as stainless steel (SS) and Ni-based alloys, used in nuclear power plants (NPPs) have demonstrated excellent performance against corrosion. This is due to formation of a protective oxide layer on the surfaces can effectively separate the underlying alloy from the surrounding environment and protect the alloy from corrosion (Lu et al., 2009; Pandey et al., 2009; Hoffelner, 2013; Chen et al., 2019; Yang et al., 2021; Wang et al., 2022). However, when these structural materials are exposed to the aggressive environments, such as the high temperature, water chemistry and high stress, the oxide layer can be damaged, leading to occurrence of localized corrosion (Landolt, 2007). Therefore, in the last decades, a number of studies have been conducted on zinc addition to the primary side water chemistry to mitigate corrosion of the structural materials and to reduce radiation dose rate during shut down (Ziemniak and Hanson, 2005; Liu et al., 2011; Liu et al., 2014; Jeon et al., 2017; Holdsworth et al., 2018). The oxide films formed on the structural materials in the aqueous environment have a duplex structure, which typically comprises of an inner layer of Cr-rich oxides and an outer layer of Fe-rich oxides (Sennour et al., 2010; Liu et al., 2014). Zn is able to modify the structure and composition of the oxide films on the structural materials by replacing $\mathrm{Ni}^{2+}$ or $\mathrm{Fe}^{2+}$ in the tetrahedral site of the spinel oxides. Kawamura et al. (1998) and Ziemniak and Hanson (2005) revealed that when $\mathrm{Zn}^{2+}$ was present at $10 \mathrm{ppb}$ or higher, the outer 
layer in the oxide film formed on Alloy 600 and 304SS became thinner while zinc chromite was formed in the inner layer, which increased the oxide film stabilization and PWSCC (primary side water chemistry stress corrosion cracking) resistance. The test on zinc injection in nuclear power plant has also been reported. It reveals that zinc addition can thin the oxide film and mitigate corrosion of metal materials such as stainless steel or nickel-based alloy (Wu et al., 2015). On the contrary, Zhang et al. (2013) observed that the oxide film of Alloy 600 becomes thicker in the presence of $\mathrm{Zn}$ at $650 \mathrm{ppb}$. Furthermore, Kim and Andresen (1997) found that the low content of zinc had little effect on the electrochemical behavior of 304SS. The difference in the results obtained from different research groups are likely due to the experimental conditions. In order to explore the discrepancies between these results, the electrochemical behavior and oxide film of 304SS in the presence of $\mathrm{Zn}$ under the high temperature and high pressure conditions are studied in this paper.

\section{EXPERIMENTAL}

\section{Materials and Methods}

Main chemical composition of 304SS is listed below (wt.\%): $\mathrm{Si}$ 0.43, Mo 0.07, Mn 1.02, Ni 9.45, Cr 17.71 and Fe balance. The specimens with a dimension of $20 \mathrm{~mm} \times 20 \mathrm{~mm} \times 2 \mathrm{~mm}$ were machined and grounded on a polishing mill with 240, 320, 800, 1,200 and 2,000 sandpaper in order. The specimens were then ultrasonically cleaned with ethanol, followed by drying with soft paper. Samples were weighed before and after corrosion.

\section{High Temperature Corrosion Tests}

The high temperature corrosion tests were performed in a $2 \mathrm{~L}$ autoclave (GCF-2L, Dalian) at a temperature of $553.15 \mathrm{~K}$ and a pressure of $6.3 \mathrm{MPa}$ for $336 \mathrm{~h}$. The aqueous solution contained $2.5 \mathrm{ppm} \mathrm{Li}$ as $\mathrm{LiOH} \cdot \mathrm{H}_{2} \mathrm{O}, 1,500 \mathrm{ppm} \mathrm{B}$ as $\mathrm{H}_{3} \mathrm{BO}_{3}$, and different $\mathrm{Zn}$ concentrations (0 ppb, $100 \mathrm{ppb}, 400 \mathrm{ppb})$ as $\mathrm{Zn}(\mathrm{CH} 3 \mathrm{COO})_{2}$. During the corrosion tests, the dissolved oxygen in the solution was controlled less than $10 \mathrm{ppb}$.

\section{Characterization Methods}

Surface morphology on the specimens was examined by an SU8010 Field Emission Scanning Electron Microscope (SEM). The oxide phases on the surfaces were analyzed using Raman Spectrum (Invia Reflex) and Grazing Incidence X-ray diffraction methods (GIXRD, Empyrean). Electrochemical workstation (Chi660e, Chenhua) and standard three electrode system were used for the electrochemical tests. The boric acid buffer solution containing $0.15 \mathrm{~mol} / \mathrm{L}$ boric acid and $0.0375 \mathrm{~mol} /$ $\mathrm{L}$ sodium was used as an electrolyte. The three-electrode system uses the alloy sample as working electrode, the platinum sheet as auxiliary electrode, and the saturated calomel electrode as reference electrode. The chemical state of the elements and composition in oxide film were performed with ESCALAB 250Xi X-ray photoelectron spectrometer (XPS). Sputtering rate of $0.2 \mathrm{~nm} / \mathrm{s}$ was used with reference to $\mathrm{SiO}_{2}$ layer. XPS data were corrected with Ni 2p3/2 peak at $852.8 \mathrm{eV}$ (Machet et al., 2004).

\section{RESULTS AND DISCUSSION}

\section{Scanning Electron Microscope Observation and Corrosion Rate}

Figure 1 presents surface morphology of the 304SS specimens after exposure to the solutions with different zinc concentrations at $553.15 \mathrm{~K}$ for $336 \mathrm{~h}$. It is shown that $\mathrm{Zn}$ addition has a significant effect on morphology of the oxide film. Figure 1A shows that the oxide particles on the surface are not uniform in size and there are some large oxide particles. The particle sizes were measured by Nano Measurer and range from 69.74 to $557.42 \mathrm{~nm}$. It has been widely though that large oxide particles are located in the outer layer of the oxide film and small oxide particles in the inner layer. When $\mathrm{Zn}$ was added to the solution at a concentration of $100 \mathrm{ppb}$, compared to Figure $\mathbf{1 A}$, the number and size of the large particles were reduced as shown in Figure 1B while the small particles remained unchanged. When $\mathrm{Zn}$ concentration was increased to $400 \mathrm{ppb}$, the large particles in the outer layer was continually reduced to the size with a range of 42.65-112.94 nm, similar to those in the inner layer, as shown in Figure 1C. These results are consistent with observed by Liu et al. (2012).

Figure $\mathbf{2}$ is the corrosion rate of the 304SS specimens at different zinc concentrations. The data were best fitted to the equation $y=a^{*} \exp (-x / b)+c$. It is shown that with increasing $\mathrm{Zn}$ concentration, reduction in weight of the sample decreases and thus the corrosion rate decreases.

\section{Grazing Incidence X-ray diffraction and Raman Spectrum}

Figure $3 \mathrm{~A}$ presents the grazing incidence XRD pattern of the $304 \mathrm{SS}$ specimen corroded in the zinc-free solution for $336 \mathrm{~h}$. The measured diffraction peaks match well those of spinel-type $\mathrm{NiFe}_{2} \mathrm{O}_{4}$. However, for the GIXRD of the sample corroded in the $\mathrm{Zn}$ solution, there was no diffraction peak observed. It is likely due to forming of the thin oxide film because when $\mathrm{Zn}$ is present, the oxide particle size decreases to less than $100 \mathrm{~nm}$, as observed in Figure 1C. The similar behavior was observed after Alloy 600 was corroded in the high temperature water (Tapping et al., 1986; Zhang et al., 2013).

Figure 3B presents Raman spectrum of the oxide film on 304SS after exposure to the solutions with 0, 100 and $400 \mathrm{ppb} \mathrm{Zn}$. In the absence of $\mathrm{Zn}$, the strongest Raman peak is located at $686 \mathrm{~cm}^{-1}$, which corresponds to the Raman-active mode A1g resulting from the $\mathrm{A}-\mathrm{O}$ vibration in the tetrahedral group $\mathrm{AO}_{4}$. The other peaks located at $336 \mathrm{~cm}^{-1}, 483 \mathrm{~cm}^{-1}$ and $590 \mathrm{~cm}^{-1}$ correspond to the other Raman-active modes, which represent the $\mathrm{B}-\mathrm{O}$ vibration characteristics in the octahedral group $\mathrm{BO}_{6}$ (Wang et al., 2002 and 2003). In comparison with the Raman spectra measured by Hosterman (2011) for $\mathrm{NiFe}_{\mathrm{x}} \mathrm{Cr}_{2-\mathrm{x}} \mathrm{O}_{4}(0 \leqq \mathrm{x}$ $\leqq 2$ ), the spectrum measured in this work is best fitted into the composition $\mathrm{NiFe}_{\mathrm{x}} \mathrm{Cr}_{2-\mathrm{x}} \mathrm{O}_{4}(1.2 \leqq \mathrm{x} \leqq 1.6)$ as the $\mathrm{F} 2 \mathrm{~g}$ (3) mode becomes detectable only at $\mathrm{x} \geqq 1$. The non-stoichiometric oxide 


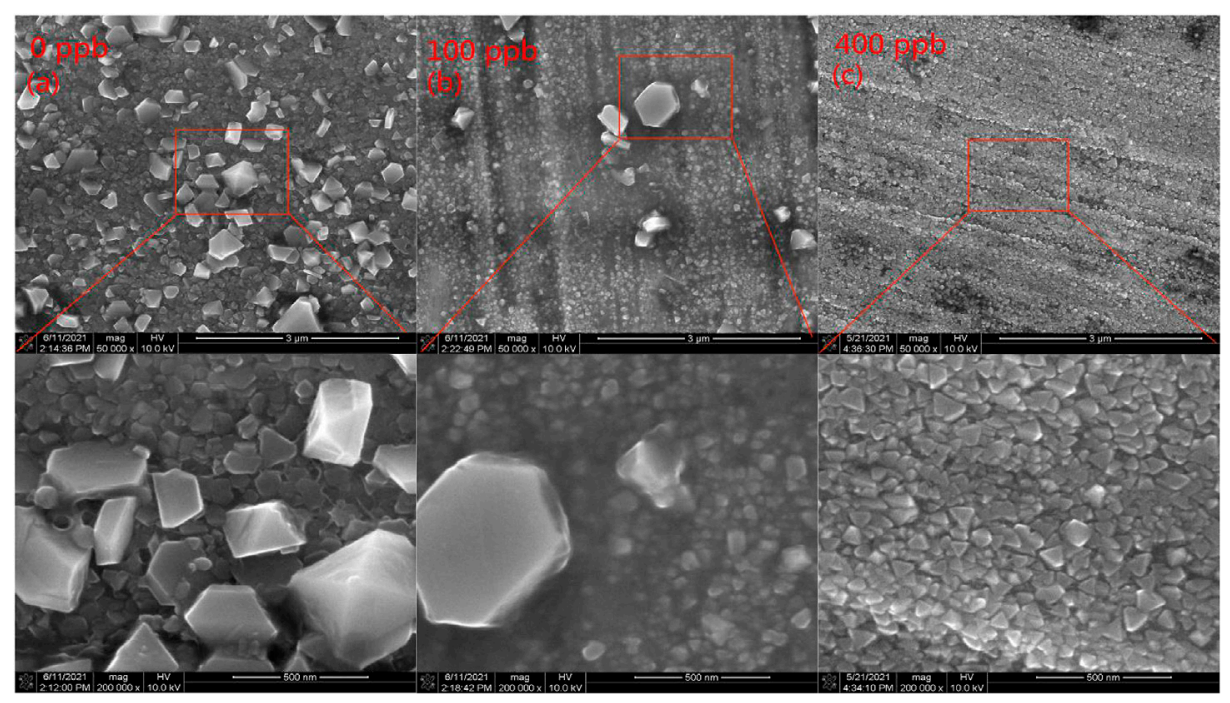

FIGURE 1 | The surface morphology of 304SS after exposure to different zinc concentrations at: (A) 0 ppb (B) 100 ppb (C) 400 ppb.

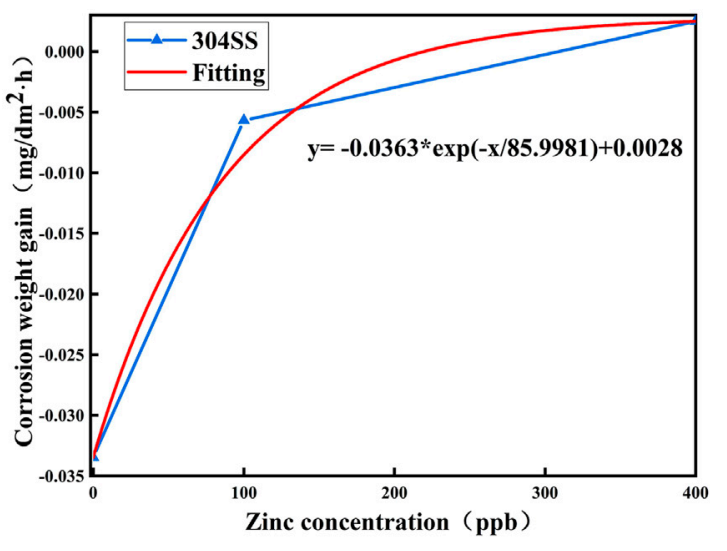

FIGURE 2 | Corrosion rate of 304SS under different zinc solutions. in the oxide film formed under the high temperature water chemistry environment without $\mathrm{Zn}$ has been also identified in the other studies (Stellwag, 1998; Huang et al., 2011; Liu et al., 2012). $\mathrm{NiCr}_{2} \mathrm{O}_{4}$ is a spinel structure while $\mathrm{NiFe}_{2} \mathrm{O}_{4}$ is an inverse spinel structure. It has been demonstrated that $\mathrm{NiFe}_{\mathrm{x}} \mathrm{Cr}_{2-\mathrm{x}} \mathrm{O}_{4}$ is a solid solution, in which inversion of the cations $\mathrm{Ni}^{2+}$ and $\mathrm{Fe}^{3+}$ between the tetrahedral and octahedral sites occurs (Allen et al., 1988). When $\mathrm{x}$ is between 0 and 1 , the entering $\mathrm{Fe}^{3+}$ has a preference to occupy the tetrahedral site, in which $\mathrm{Ni}^{2+}$ is forced to move to the octahedral site (Park and Suito, 1992). When $\mathrm{x}$ is greater than 1, the trivalent iron substitutes for chromium in the remaining octahedral sites. Thus, when adding to the solution, $\mathrm{Zn}$ occupied the octahedral site. Therefore, the oxide formed on the sample surface in the $\mathrm{Zn}$-containing solution can be expressed in the form of $\mathrm{Zn}_{\mathrm{x}} \mathrm{Ni}_{1-\mathrm{x}} \mathrm{Fe}_{\mathrm{y}} \mathrm{Cr}_{2-\mathrm{y}} \mathrm{O}_{4}$. Figure 3B shows that when $\mathrm{Zn}$ was added to the solution, intensity of the main peak at $686 \mathrm{~cm}^{-1}$
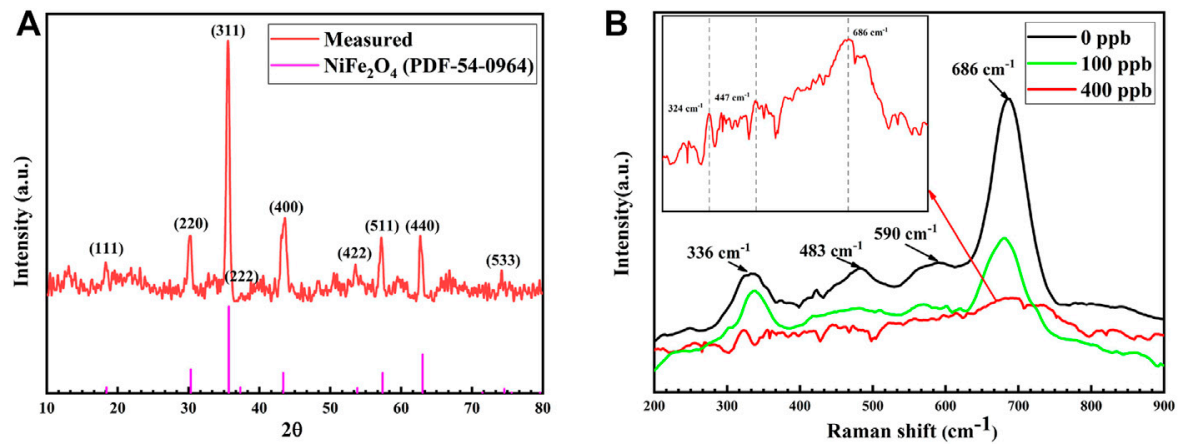

FIGURE 3 | (A) GIXRD of the oxide film on 304SS after exposure to the Zn-free solution (B)

(B) Raman spectrum of the oxide film on 304SS after exposure to the solutions with 0,100 and $400 \mathrm{ppb} \mathrm{Zn}$. 

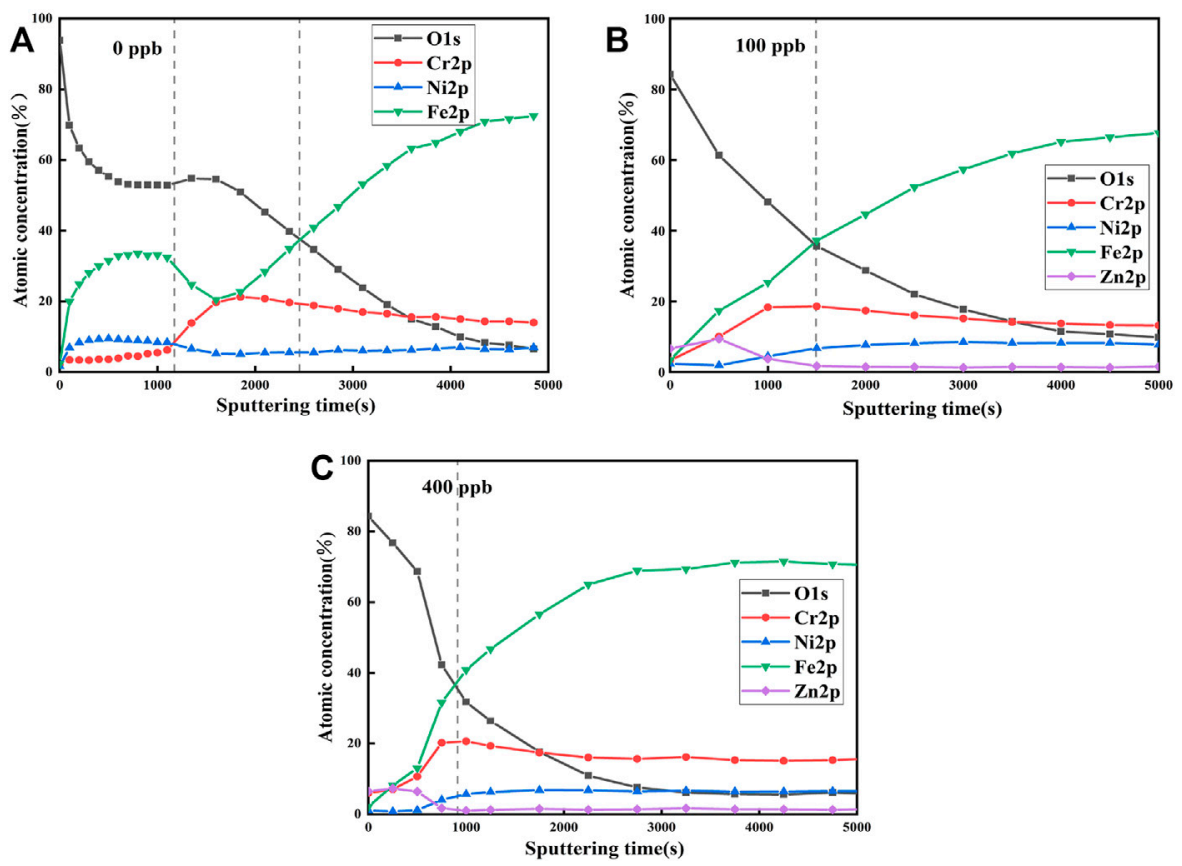

FIGURE 4 | XPS depth analysis of oxide film on 304SS in non-zinc and zinc solutions at $553.15 \mathrm{k}$ for $336 \mathrm{~h}$ : (A) 0 ppb (B) 100 ppb (C) 400 ppb.

decreased more dramatically than the other peaks. Weakening of the Raman peak could be also attributed to forming of fine oxide particles and thin oxide film in the presence $\mathrm{Zn}$. This is consistent with the observations by SEM and GIXRD. Thus Raman spectrum is a useful tool to characterize the oxide film composition in the presence of $\mathrm{Zn}$.

\section{X-ray Photoelectron Spectrometer Analysis}

Depth profiles of the oxide films formed on 304SS in the zinc-free and zinc solutions at $553.15 \mathrm{k}$ for $336 \mathrm{~h}$ were measured using the XPS technique and are presented in Figure 4. The interface between the oxide film and metal substrate is usually defined at the point where the intensity of oxygen level is $50 \%$ of its initial value (Machet et al., 2002). It can be seen from Figure 4 that the sputtering time of XPS on the metal substrate formed at different Zn concentrations is 2,600, 1,500 and $850 \mathrm{~s}$, respectively. As the XPS sputtering rate of $0.2 \mathrm{~nm} / \mathrm{s}$ was used, the thicknesses of the oxide films formed at three $\mathrm{Zn}$ concentrations are 520, 300 and $170 \mathrm{~nm}$, respectively. Thus, $\mathrm{Zn}$ addition significantly leads to thinning of the oxide film, which is consistent with the SEM observations.

Figure 4A shows that in the absence of zinc, the outer layer of the oxide film was rich in $\mathrm{Fe}$ and the inner layer was rich in $\mathrm{Cr}$, which is a typical duplex structure of the oxide film (The outer layer between the first dotted line and the y axis and the inner layer between the two dotted lines). The oxide film is formed by re-deposition of dissolved metal ions during corrosion process. As diffusion rates of $\mathrm{Fe}$ and $\mathrm{Ni}$ cross the interface between metal and oxide film are faster than that of $\mathrm{Cr}$; $\mathrm{Fe}$ and $\mathrm{Ni}$ are enriched in the outer layer, and $\mathrm{Cr}$ is enriched in the inner layer (Stellwag, 1998; Lee et al., 2021).
When zinc was present, $\mathrm{Ni}$ and $\mathrm{Fe}$ in the oxide layer were depleted while $\mathrm{Cr}$ in the inner layer was enriched up to $20 \%$ at., as shown in Figures 4B,C. In addition, $\mathrm{Zn}$ with a concentration up to $8 \%$ at was incorporated to the oxide film. This is due to the fact that $\mathrm{Zn}^{2+}$ can replace $\mathrm{Fe}^{2+}$ and $\mathrm{Ni}^{2+}$ in the spinel oxide of the oxide film (Ziemniak and Hanson, 2005; Huang et al., 2011; Liu et al., 2011). The formed oxide film is dense with less cation vacancies and has low solubility, which prevents metal ions from movement and oxygen from diffusion. Therefore, $\mathrm{ZnCr}_{2} \mathrm{O}_{4}$ is dominant in the inner layer formed in the presence of $\mathrm{Zn}$ while Fe-based spinel oxide in the outer layer was recrystallized to form small size particles.

After the 304SS specimens were exposed to the simulated primary water chemistry with 0,100 and $400 \mathrm{ppb}$ zinc for $336 \mathrm{~h}$, the spectra of $\mathrm{Ni} 2 \mathrm{p} 3 / 2, \mathrm{Fe} 2 \mathrm{p} 3 / 2$, Cr 2p3/2, O 1 s and $\mathrm{Zn} \mathrm{2p3/2}$ were measured and presented in Figure 5. The XPS spectra of $\mathrm{Ni}$ $2 \mathrm{p} 3 / 2$ in the oxide film formed in the absence of $\mathrm{Zn}$ can be deconvoluted to the $\mathrm{Ni}^{0}$ peak at $852.59 \mathrm{eV}, \mathrm{NiO}$ at $854.31 \mathrm{eV}$ and satellite peak of the $\mathrm{Ni}^{0}$ at $858.67 \mathrm{eV}$, with $\mathrm{Ni}^{0}$ accounting for 46.87\% (Dickinson et al., 1997; Lee et al., 2021). Among these peaks, the strongest peak of $\mathrm{Ni}^{0}$ could be attributed to reduction of $\mathrm{Ni}^{2+}$ during the Ar ion beam sputtering (Machet et al., 2002). Three peaks of $852.82,854.23$ and $855.88 \mathrm{eV}$, corresponding to $\mathrm{Ni}^{0}, \mathrm{NiO}$ and $\mathrm{Ni}^{2+}$, respectively, were observed after adding $100 \mathrm{ppb}$ zinc into the solution, with $\mathrm{Ni}^{0}$ accounting for $69.34 \%$. After $400 \mathrm{ppb}$ zinc was added into the solution, two peaks appeared at 852.72 and $855.28 \mathrm{eV}$, corresponding to $\mathrm{Ni}^{0}$ and $\mathrm{Ni}^{2+}$, respectively, with $\mathrm{Ni}^{0}$ accounting for $74.56 \% . \mathrm{Ni}^{2+}$ may be in the form of $\mathrm{Ni}(\mathrm{OH})_{2}, \mathrm{NiFe}_{2} \mathrm{O}_{4}$ and $\mathrm{NiCr}_{2} \mathrm{O}_{4}$ (Lee et al., 2021). Comparison of the percentage of $\mathrm{Ni}^{0}$ in the three $\mathrm{Zn}$ 

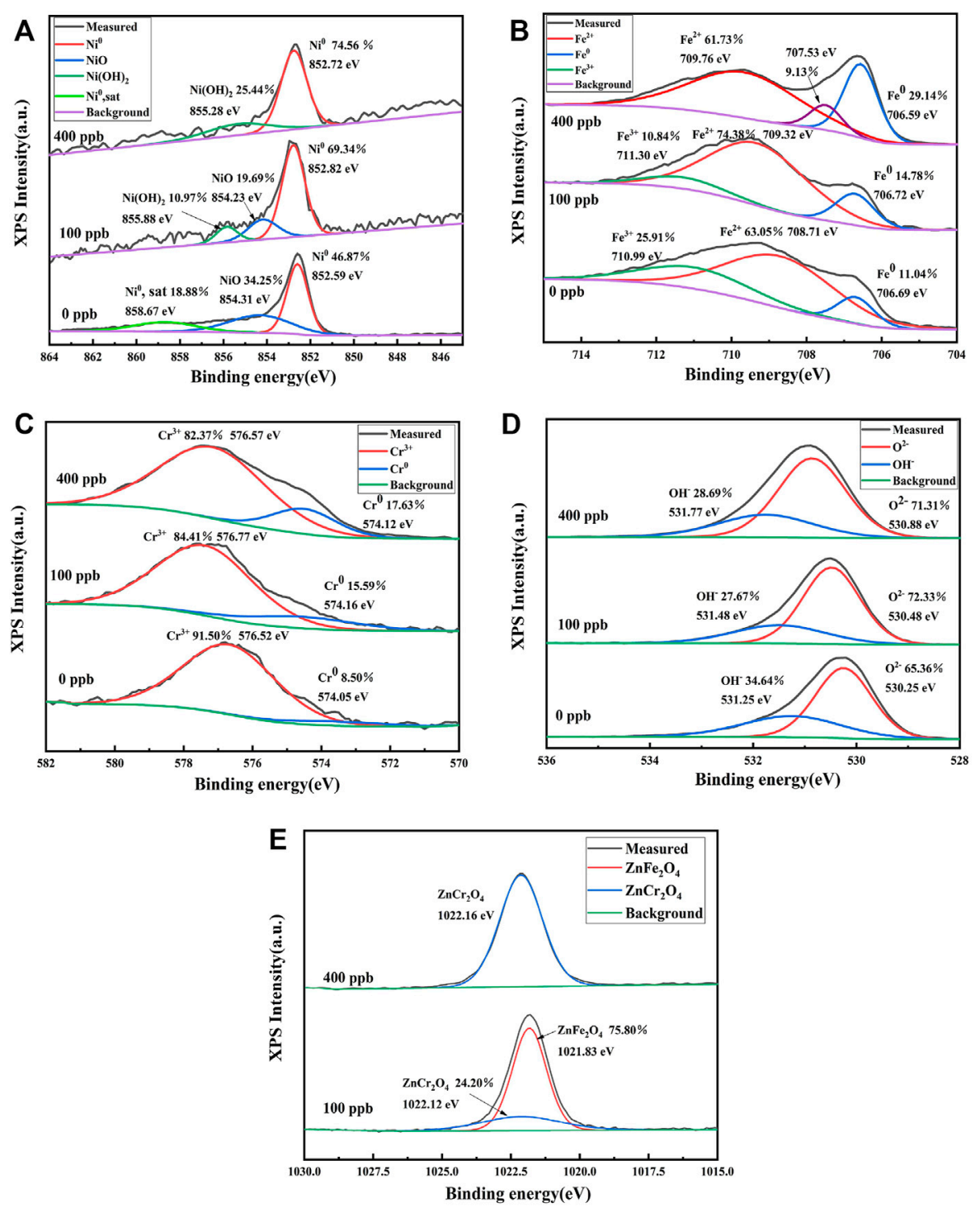

FIGURE 5 | The XPS spectra of oxide films on 304SS exposed to 0, 100 and 400 ppb Zn solutions after sputtering 500 s: (A) Ni 2p3/2 (B) Fe 2p3/2 (C) Cr 2p3/ 2 (D) $O 1 \mathrm{~s}$ (E) Zn 2p3/2.

solutions reveals that more $\mathrm{Ni}^{0}$ can be detected after $\mathrm{Zn}$ addition. This implies that the oxide film becomes thinner after $\mathrm{Zn}$ addition.

The XPS spectrum of Fe 2p3/2 in the oxide film formed in the $\mathrm{Zn}$-free primary water chemistry can be deconvoluted to $\mathrm{Fe}^{3+}$ at $710.99 \mathrm{eV}, \mathrm{Fe}^{2+}$ at $708.71 \mathrm{eV}$ and $\mathrm{Fe}^{0}$ at $706.69 \mathrm{eV}$. The $\mathrm{Fe}^{2+}$ and $\mathrm{Fe}^{3+}$ peaks could be attributed to presence of $\mathrm{FeCr}_{2} \mathrm{O}_{4}, \mathrm{NiFe}_{2} \mathrm{O}_{4}$ and $\mathrm{Fe}_{3} \mathrm{O}_{4}$ (Lee et al., 2021). The XPS spectrum of $\mathrm{Cr} 2 \mathrm{p} 3 / 2$ can be deconvoluted to $\mathrm{Cr}^{0}$ at 574.05 $\mathrm{eV}$, and $\mathrm{Cr}^{3+}$ at $576.52 \mathrm{eV}$. The $\mathrm{Cr}^{3+}$ peak could be assigned to $\mathrm{Cr}_{2} \mathrm{O}_{3}, \mathrm{NiCr}_{2} \mathrm{O}_{4}, \mathrm{FeCr}_{2} \mathrm{O}_{4}$ and $\mathrm{ZnCr}_{2} \mathrm{O}_{4}$ (Lee et al., 2021). The XPS spectrum of $\mathrm{O} 1 \mathrm{~s}$ can be deconvoluted to $\mathrm{O}^{2-}$ at $530.25 \mathrm{eV}$, and $\mathrm{OH}^{-}$at $531.25 \mathrm{eV}$ (Lee et al., 2021). The XPS peak of $\mathrm{Zn} 2 \mathrm{p} 3 / 2$ can be deconvoluted to $\mathrm{ZnFe}_{2} \mathrm{O}_{4}$ at $1,021.83 \mathrm{eV}$ and $\mathrm{ZnCr}_{2} \mathrm{O}_{4}$ at 1,022.12 eV (Liu et al., 2011).
When $\mathrm{Zn}$ is added at a concentration of $400 \mathrm{ppb}$, the main peak is assigned to $\mathrm{ZnCr}_{2} \mathrm{O}_{4}$ with no observation of $\mathrm{ZnFe}_{2} \mathrm{O}_{4}$.

\section{Effect of Zn on Electrochemical Properties of 304SS}

Figure 6 shows the potentiodynamic polarization curves and Mott-Schottky curves of 304SS after exposure to the simulated primary water environments with different $\mathrm{Zn}$ concentrations for $336 \mathrm{~h}$. The corrosion current densities of $304 \mathrm{SS}$ in the presence of $\mathrm{Zn}$ at 0,100 and $400 \mathrm{ppb}$ are $3.33,1.81$ and $0.87 \mu \mathrm{A} / \mathrm{cm}^{2}$, respectively. The change in corrosion potential with increase in the $\mathrm{Zn}$ concentration is insignificant. Decrease in the current density with increasing the $\mathrm{Zn}$ concentration indicates 

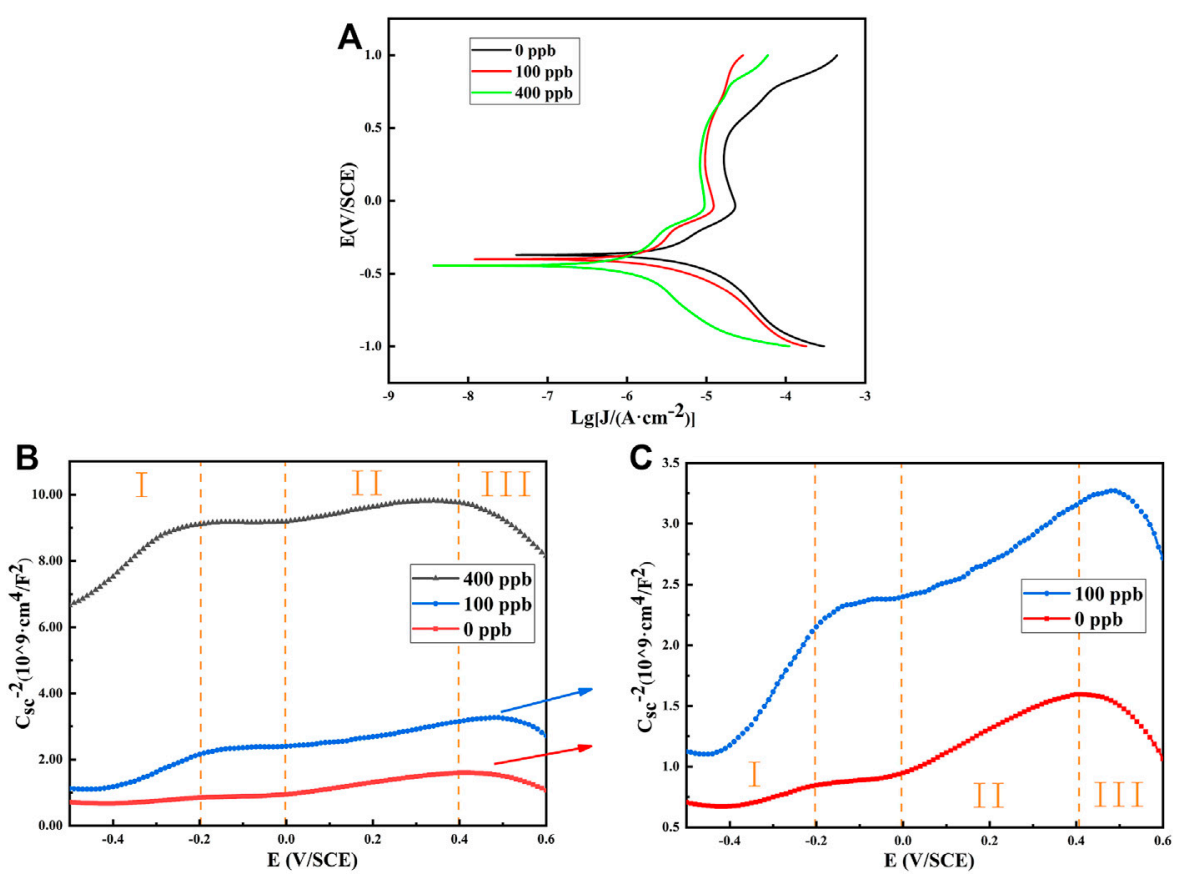

FIGURE 6 | Potentiodynamic polarization curve and Mott-Schottky curve of 304SS after exposure to different Zn solutions at 553.15 K: (A) Potentiodynamic polarization curve of $304 S S$ with 0, 100 and 400 ppb Zn (B) Mott-Schottky curve of $304 S S$ with 0, 100 and 400 ppb Zn (C) Mott-Schottky curve of $304 S S$ with 0 and $100 \mathrm{ppb}$ Zn.

TABLE 1 | Calculated defect densities in oxide layers formed in different $\mathrm{Zn}$ solutions.

\begin{tabular}{|c|c|c|c|}
\hline Conditions (ppb) & $\begin{array}{c}\text { Region } \\
\text { I } N_{D}\left(10^{21} \mathrm{~cm}^{-3}\right)\end{array}$ & $\begin{array}{c}\text { Region } \\
\text { II } \mathrm{N}_{\mathrm{D}}\left(10^{21} \mathrm{~cm}^{-3}\right)\end{array}$ & $\begin{array}{c}\text { Region } \\
\text { III } \mathrm{N}_{\mathrm{A}}\left(10^{21} \mathrm{~cm}^{-3}\right)\end{array}$ \\
\hline 0 & 14.25 & 7.51 & 4.14 \\
\hline 100 & 2.65 & 7.20 & 2.49 \\
\hline 400 & 1.25 & 6.09 & 1.59 \\
\hline
\end{tabular}

that $\mathrm{Zn}$ incorporation into the oxide film improves the resistance of the 304SS material against corrosion.

Since the passive films formed on 304SS contain large number of defects and holes, they exhibit characteristic of semiconducting property. Therefore, they can be characterized by the MottSchottky equation as follows.

$$
\frac{1}{C^{2}}=\frac{2}{q N \varepsilon \varepsilon_{0}}\left(E-E_{F B}-\frac{k T}{q}\right)
$$

where, $\varepsilon$ is the dielectric constant of the passive film; $\varepsilon_{0}$ is the vacuum permittivity $\left(8.854 \times 10^{-14} \mathrm{~F} / \mathrm{cm}\right)$; $\mathrm{q}$ is elementary charge of electrons $\left(1.602 \times 10^{-19} \mathrm{C},-\mathrm{q}\right.$ for holes $)$; $\mathrm{N}$ is number density of acceptors or donors; $\mathrm{E}$ and $\mathrm{E}_{\mathrm{FB}}$ are the applied and flat band potentials (V), respectively; $\mathrm{k}$ is Boltzmann's constant $\left(1.38 \times 10^{-23} \mathrm{~J} / \mathrm{K}\right)$ and $\mathrm{T}$ is the absolute temperature $(\mathrm{K})$.

The capacitance data of the passive films formed on 304SS after exposed to the $\mathrm{Zn}$ solutions were measured as a function of applied potential and are presented in Figures $6 \mathbf{B}, \mathbf{C}$.
According to the slope of the linear part in the three regions of the curve, defect density of the oxide film can be calculated by the Mott-Schottky equation. The results are shown in Table 1. When the slope is positive, the oxide film exhibits n-type semiconductor. When the slope is negative, the oxide film exhibits p-type semiconductor. According to Feng et al. (2010), the passivation films composed of $\mathrm{Cr}_{2} \mathrm{O}_{3}$ and $\mathrm{NiO}$ are generally p-type semiconductors, while the passivation films composed of $\mathrm{Fe}$ oxides are generally n-type semiconductors. The results in Table 1 show that in the regions I and region II, the oxide film exhibits n-type semiconductor, and in the regions III, the oxide film exhibits P-type semiconductor, indicating that the surface oxide film is a composite structure. In addition, it is found that the defect densities of the sample after zinc addition all decrease in the three potential regions. Decrease in carrier concentration of the passive film formed in the presence of $\mathrm{Zn}$ indicates improvement in the corrosion resistance of 304SS. Similar result was also observed in other study (Montemor et al., 2000; Lim et al., 2021).

\section{Solubilities of the Related Spinel Oxides}

The SEM and XPS studies reveal that the oxide films formed on 304SS under simulated primary circuit environments are a duplex structure composed of Fe-based spinel oxide and Cr-based spinel oxide. The order of standard Gibbs free energies of various spinels is as follows (Liu et al., 2011): $\Delta \mathrm{G}\left(\mathrm{ZnCr}_{2} \mathrm{O}_{4}\right)<\Delta \mathrm{G}\left(\mathrm{FeCr}_{2} \mathrm{O}_{4}\right)$ $<\Delta \mathrm{G} \quad\left(\mathrm{NiCr}_{2} \mathrm{O}_{4}\right)$ and $\Delta \mathrm{G} \quad\left(\mathrm{ZnFe}_{2} \mathrm{O}_{4}\right)<\Delta \mathrm{G} \quad\left(\mathrm{Fe}_{3} \mathrm{O}_{4}\right)<\Delta \mathrm{G}$ $\left(\mathrm{NiFe}_{2} \mathrm{O}_{4}\right)$. According to the thermodynamic law, stability of 


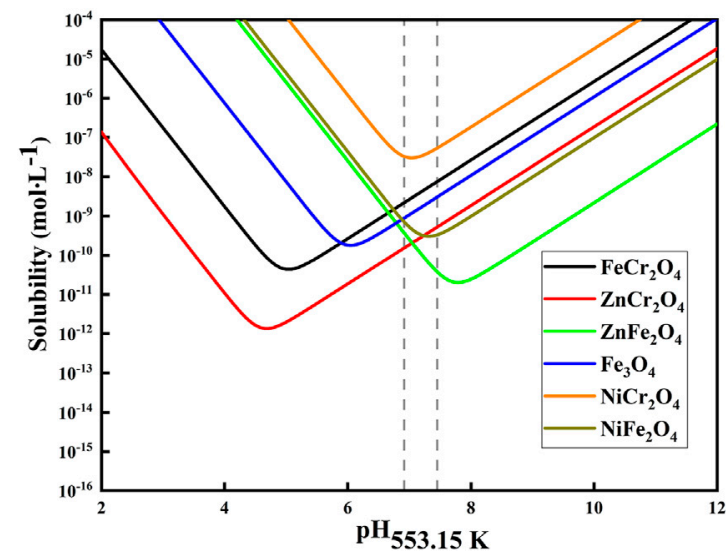

FIGURE 7 | Solubilities of spinel oxides formed on 304SS in the high temperature water.

these spinel oxides is in the reverse order. Therefore, when $\mathrm{Zn}$ is added to the solution, $\mathrm{Zn}$ can replace $\mathrm{Ni}^{2+}$ in $\mathrm{NiFe}_{2} \mathrm{O}_{4}$ or $\mathrm{Fe}^{2+}$ in $\mathrm{Fe}_{3} \mathrm{O}_{4}$ to form more stable $\mathrm{ZnFe}_{2} \mathrm{O}_{4}$ in the outer layer as shown in Eq. 1, while $\mathrm{Zn}$ can replace $\mathrm{Ni}^{2+}$ in $\mathrm{NiCr}_{2} \mathrm{O}_{4}$ or $\mathrm{Fe}^{2+}$ in $\mathrm{FeCr}_{2} \mathrm{O}_{4}$ in the inner layer to form more stable $\mathrm{ZnCr}_{2} \mathrm{O}_{4}$ as shown in Eq. 2. The thermodynamic analysis is in full agreement with the observations from the SEM and XPS data.

$$
\begin{aligned}
& \mathrm{NiFe}_{2} \mathrm{O}_{4}+\mathrm{Zn}^{2+}=\mathrm{ZnFe}_{2} \mathrm{O}_{4}+\mathrm{Ni}^{2+} \\
& \mathrm{NiCr}_{2} \mathrm{O}_{4}+\mathrm{Zn}^{2+}=\mathrm{ZnCr}_{2} \mathrm{O}_{4}+\mathrm{Ni}^{2+}
\end{aligned}
$$

On the other hand, the solubilities of the related spinel oxides in the oxide films at $553.15 \mathrm{k}$ are calculated using the equation and the thermodynamic data in Ref. (Liu et al., 2011) and presented in Figure 7. The SEM and XPS analyses reveal that the oxide films are composed of $\mathrm{Cr}$-rich spinel and $\mathrm{Fe}$ rich spinel oxides. Figure 7 shows that the solubilites of $\mathrm{Zn}$ spinel oxides $\mathrm{ZnCr}_{2} \mathrm{O}_{4}$ and $\mathrm{ZnFe}_{2} \mathrm{O}_{4}$ under the primary side water conditions at pH 7.0 and at $553.15 \mathrm{k}$ (between two dash lines) are lower compared to the corresponding $\mathrm{Ni}$ and $\mathrm{Fe}$ spinel oxides. Therefore, when $\mathrm{Zn}$ is added to the solution, the $\mathrm{Zn}$ spinel oxides prefer to form due to their lower solubility, which makes the material more resistant to corrosion.

\section{REFERENCES}

Allen, G. C., Jutson, J. A., and Tempest, P. A. (1988). Characterization of NickelChromium-Iron Spinel-type Oxides. J. Nucl. Mater. 158, 96-107. doi:10.1016/ 0022-3115(88)90159-6

Chen, J., Lu, Z., Meng, F., Xu, X., Xiao, Q., Kim, H.-S., et al. (2019). The Corrosion Behaviour of alloy 690 Tube in Simulated PWR Secondary Water with the Effect of Solid Diffusing Hydrogen. J. Nucl. Mater. 517, 179-191. doi:10.1016/j. jnucmat.2019.02.019

Dickinson, T., Povey, A. F., and Sherwood, P. M. A. (1977). Dissolution and Passivation of Nickel. An X-ray Photoelectron Spectroscopic Study. J. Chem. Soc. Faraday Trans. 1 73, 327-343. doi:10.1039/F19777300327

Feng, Z., Cheng, X., Dong, C., Xu, L., and Li, X. (2010). Passivity of 316L Stainless Steel in Borate Buffer Solution Studied by Mott-Schottky Analysis, Atomic

\section{CONCLUSION}

The oxide films formed on 304SS exposed to the different $\mathrm{Zn}$ solutions at $553.15 \mathrm{~K}$ are characterized by SEM, GIXRD, Raman spectrum, XPS, polarization and Mott-Schottky curves.

1) When $\mathrm{Zn}$ is present in the solution, the oxide particles in the oxide film formed on 304 SS becomes smaller, leading to the oxide film being thinner. The corrosion rate of 304SS was reduced after zinc addition.

2) With increasing $\mathrm{Zn}$ concentration, the corrosion current density of $304 \mathrm{SS}$ and carrier concentration of the oxide film decrease. This indicates that corrosion resistance of $304 \mathrm{SS}$ is enhanced in the presence of $\mathrm{Zn}$. In addition, intensity of the main Raman peak for $\mathrm{NiFe}_{\mathrm{x}} \mathrm{Cr}_{2-\mathrm{x}} \mathrm{O}_{4}(1.2 \leqq$ $\mathrm{x} \leqq 1.6)$ decreases with increasing $\mathrm{Zn}$ concentration.

3) Thermodynamic calculations show that the solubilities of the related spinel oxides (like $\mathrm{NiFe}_{2} \mathrm{O}_{4}, \mathrm{FeCr}_{2} \mathrm{O}_{4}$ ) are in good agreement the experimental observations. Compared to other spinel oxides, the $\mathrm{Zn}$-containing spinel oxides i.e., $\mathrm{ZnFe}_{2} \mathrm{O}_{4}$ and $\mathrm{ZnCr}_{2} \mathrm{O}_{4}$ have lower solubilities, leading to better corrosion resistance of the material.

\section{DATA AVAILABILITY STATEMENT}

The original contributions presented in the study are included in the article/Supplementary Material, further inquiries can be directed to the corresponding author.

\section{AUTHOR CONTRIBUTIONS}

All authors listed have made a substantial, direct, and intellectual contribution to the work and approved it for publication.

\section{FUNDING}

This work was supported by Fujian Science and Technology Innovation Laboratory for Optoelectronic Information of China (2021ZR108) and the National Natural Science Foundation of China (Grant No. 52001302).

Absorption Spectrometry and X-ray Photoelectron Spectroscopy. Corrosion Sci. 52, 3646-3653. doi:10.1016/j.corsci.2010.07.013

Hoffelner, W. (2013). "Nuclear Plants," in Materials for Nuclear Plants (London: Springer), 1-64. Available at: https://link.springer.com/chapter/10.1007/978-14471-2915-8_1. doi:10.1007/978-1-4471-2915-8_1

Holdsworth, S., Scenini, F., Burke, M. G., Bertali, G., Ito, T., Wada, Y., et al. (2018). The Effect of High-Temperature Water Chemistry and Dissolved Zinc on the Cobalt Incorporation on Type 316 Stainless Steel Oxide. Corrosion Sci. 140, 241-251. doi:10.1016/j.corsci.2018.05.041

Hosterman, B. D. (2011). Raman Spectroscopic Study of Solid Solution Spinel Oxides. UNLV Theses, Dissertations, Professional Papers and Capstones. 1087. Las Vegas: University of Nevada. doi:10.34917/2476131

Huang, J., Liu, X., Han, E.-H., and Wu, X. (2011). Influence of Zn on Oxide Films on Alloy 690 in Borated and Lithiated High Temperature Water. Corrosion Sci. 53, 3254-3261. doi:10.1016/j.corsci.2011.06.001 
Jeon, S.-H., Lee, E.-H., and Hur, D. H. (2017). HEffects of Dissolved Hydrogen on General Corrosion Behavior and Oxide Films of alloy 690TT in PWR Primary Water. J. Nucl. Mater. 485, 113-121. doi:10.1016/j.jnucmat.2016.12.020

Kawamura, H., Hirano, H., Shirai, S., Takamatsu, H., Matsunaga, T., Yamakota, K., et al. (1998). "The Effect of Zinc Addition to Simulated PWR Primary Water on the PWSCC Resistance, Crack Growth Rate and Surface Oxide Films Characteristics of Prefilmed Alloy 600," in Paper presented at the CORROSION 98, San Diego, CA, March 22, 1998, 623-636. Available at: https://onepetro.org/NACECORR/proceedings-abstract/CORR98/All-CORR98/ NACE-98141/127597.

Kim, Y. J., and Andresen, P. (1997). "Effect of Zinc and Copper Additions on Catalytic Response of Noble Metal Alloyed 304 SS in High Temperature Water," in Paper presented at the Corrosion97, New Orleans, Louisiana, March 09, 1997. Available at: https://onepetro.org/NACECORR/ proceedings-abstract/CORR97/All-CORR97/NACE-97112/113286.

Landolt, D. (2007). Corrosion and Surface Chemistry of Metals. CH-1015 Lausanne, Switzerland: EPFL Press. doi:10.1201/9781439807880

Lee, H. B., Chen, J., Meng, S., Jang, C., Park, S. H., Xiao, Q., et al. (2021). Characterization of Oxide Layers Formed on Type 316 Stainless Steel Exposed to the Simulated PWR Primary Water Environment with Varying Dissolved Hydrogen and Zinc Concentrations. J. Nucl. Mater. 556, 153193. doi:10.1016/J.jnucmat.2021.153193

Lim, D.-S., Jeon, S.-H., Bae, B. J., Choi, J., Song, K. M., and Hur, D. H. (2021). Effect of Zinc Addition Scenarios on General Corrosion of Alloy 690 in Borated and Lithiated Water at $330^{\circ}$ C. Corrosion Sci. 189, 109627. doi:10.1016/j.corsci.2021. 109627

Liu, X., Han, E.-H., and Wu, X. (2014). Effects of pH Value on Characteristics of Oxide Films on 316L Stainless Steel in Zn-Injected Borated and Lithiated High Temperature Water. Corrosion Sci. 78, 200-207. doi:10.1016/j.corsci.2013. 09.017

Liu, X., Wu, X., and Han, E.-H. (2012). HEffect of Zn Injection on Established Surface Oxide Films on 316L Stainless Steel in Borated and Lithiated High Temperature Water. Corrosion Sci. 65, 136-144. doi:10.1016/j.corsci.2012. 08.022

Liu, X., Wu, X., and Han, E.-H. (2011). Influence of Zn Injection on Characteristics of Oxide Film on 304 Stainless Steel in Borated and Lithiated High Temperature Water. Corrosion Sci. 53, 3337-3345. doi:10.1016/j.corsci.2011.06.011

Lu, Y. C., Goszczynski, G., and Ramamurthy, S. (2009). Degradation of alloy 800 under Steam Generator Secondary Side Crevice Conditions. Int. Conf. Nucl. Eng. 43512, 649-657. doi:10.1115/ICONE17-75695

Machet, A., Galtayries, A., Marcus, P., Combrade, P., Jolivet, P., and Scott, P. (2002). XPS Study of Oxides Formed on Nickel-Base Alloys in HighTemperature and High-Pressure Water. Surf. Interf. Anal. 34, 197-200. doi:10.1002/sia.1282

Machet, A., Galtayries, A., Zanna, S., Klein, L., Maurice, V., Jolivet, P., et al. (2004). XPS and STM Study of the Growth and Structure of Passive Films in High Temperature Water on a Nickel-Base alloy. Electrochimica Acta 49, 3957-3964. doi:10.1016/j.electacta.2004.04.032

Montemor, M. F., Ferreira, M. G. S., Hakiki, N. E., and Da Cunha Belo, M. (2000). Chemical Composition and Electronic Structure of the Oxide Films Formed on 316L Stainless Steel and Nickel Based Alloys in High Temperature Aqueous Environments. Corrosion Sci. 42, 1635-1650. doi:10.1016/S0010-938X(00) 00012-3

Pandey, M. D., Datla, S., Tapping, R. L., and Lu, Y. C. (2009). The Estimation of Lifetime Distribution of Alloy 800 Steam Generator Tubing. Nucl. Eng. Des. 239, 1862-1869. doi:10.1016/j.nucengdes.2009.05.027
Park, B.-H., and Suito, H. (1992). Thermodynamic Properties of NiCr2O4NiFe2O4 Spinel Solid Solution. Thermochim. Acta 205, 289-298. doi:10. 1016/0040-6031(92)85271-V

Sennour, M., Marchetti, L., Martin, F., Perrin, S., Molins, R., and Pijolat, M. (2010). A Detailed TEM and SEM Study of Ni-Base Alloys Oxide Scales Formed in Primary Conditions of Pressurized Water Reactor. J. Nucl. Mater. 402, 147-156. doi:10.1016/j.jnucmat.2010.05.010

Stellwag, B. (1998). The Mechanism of Oxide Film Formation on Austenitic Stainless Steels in High Temperature Water. Corrosion Sci. 40, 337-370. doi:10.1016/S0010-938X(97)00140-6

Tapping, R. L., Davidson, R. D., Mcalpine, E., and Lister, D. H. (1986). The Composition and Morphology of Oxide Films Formed on Type 304 Stainless Steel in Lithiated High Temperature Water. Corrosion Sci. 26, 563-576. doi:10. 1016/0010-938X(86)90024-7

Wang, S., Zheng, K., Zheng, Z., Long, J., and Wang, J. (2022). Oxidation Behaviour and Microstructure Evolution of Zr-Containing Steel under Continuous HighTemperature Exposure. Mater. Chem. Phys. 275, 125324. doi:10.1016/j. matchemphys.2021.125324

Wang, Z., Lazor, P., Saxena, S. K., and Artioli, G. (2002). High-Pressure Raman Spectroscopic Study of Spinel (ZnCr2O4). J. Solid State. Chem. 165, 165-170. doi:10.1006/jssc.2002.9527

Wang, Z., Schiferl, D., Zhao, Y., and O'Neill, H. S. C. (2003). High Pressure Raman Spectroscopy of Spinel-type Ferrite ZnFe2O4. J. Phys. Chem. Sol. 64, 2517-2523. doi:10.1016/j.jpcs.2003.08.005

Wu, X., Liu, X., Han, E., and Wei, K. (2015). Relationship between PWR Primary Water Chemistry and Material Degradation. J. Shanghai Univ. (Natural Sci. Edition) 21, 141-151. doi:10.3969/j.issn.1007-2861.2014.04.015

Yang, L., Wang, J., Yang, R., Yang, S., Jia, Y., Chen, M., et al. (2021). Oxidation Behavior of a Nanocrystalline Coating with Low Ta Content at High Temperature. Corrosion Sci. 180, 109182. doi:10.1016/j.corsci. 2020.109182

Zhang, S., Tan, Y., and Liang, K. (2013). Photoelectrochemical Study on Semiconductor Properties of Oxide Films on Alloy 600 in High Temperature Water with ZnO Addition. J. Nucl. Mater. 434, 43-48. doi:10. 1016/j.jnucmat.2012.11.024

Ziemniak, S. E., and Hanson, M. (2006). Zinc Treatment Effects on Corrosion Behavior of 304 Stainless Steel in High Temperature, Hydrogenated Water. Corrosion Sci. 48, 2525-2546. doi:10.1016/j.corsci.2005.10.014

Conflict of Interest: The authors declare that the research was conducted in the absence of any commercial or financial relationships that could be construed as a potential conflict of interest.

Publisher's Note: All claims expressed in this article are solely those of the authors and do not necessarily represent those of their affiliated organizations, or those of the publisher, the editors and the reviewers. Any product that may be evaluated in this article, or claim that may be made by its manufacturer, is not guaranteed or endorsed by the publisher.

Copyright (c) $2022 \mathrm{Wei}, \mathrm{Lin}, \mathrm{Liu}, \mathrm{Wu}$ and Chi. This is an open-access article distributed under the terms of the Creative Commons Attribution License (CC BY). The use, distribution or reproduction in other forums is permitted, provided the original author(s) and the copyright owner(s) are credited and that the original publication in this journal is cited, in accordance with accepted academic practice. No use, distribution or reproduction is permitted which does not comply with these terms. 